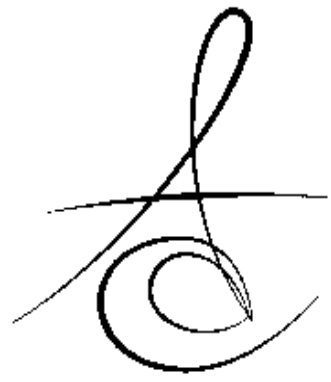

Makale Kodu/Article code: 2509

Makale Gönderilme tarihi; 17.12.2015

Kabul Tarihi: 04.04.2016

\section{DİŞ HEKİMLİĞİNDE BOTOKS: DERLEME}

\author{
BOTOX IN DENTISTRY: REVIEW
}

\section{öz}

Botulinum nörotoksini anaerob Clostridium botulinum bakterisi tarafından üretilen bir toksindir. İsmini botulinum toksininin ilk hecelerinden alan botoks, günümüzde hem tedavi amaçlı hem de kozmetik alanında kullanılmaktadır. Botulinum toksininin 7 serotipi bulunmaktadır. En çok kullanılan tipi toksin A'dır. Toksin kaslara enjekte edildiği zaman sinir hücrelerine etki ederek kısmi ve geçici süre ile paraliz oluşturmakta ve bu şekilde kasın fazla kasılmasını önlemektedir. Piyasada tip A başta olmak üzere tip B'yi de içeren ve çeşitli isimler adı altında bulunan botulinum toksinleri mevcuttur. Her bir preparat kişiye özel olarak hazırlanmakta ve bir diğeri ile karıştırılamamaktadır. Günümüzde botoks tedavisi diş hekimliği alanında da geniş kullanım alanı bulmuştur. Terapötik amaçla perioral bölgede uygulanmaya başlayan botulinum toksini temporomandibular eklem rahatsızlıkları, bruksizm, görünür dişeti, masseter hipertrofisi, tükürük bezleri problemleri gibi çeşitli alanlarda kullanılmaktadır. Bu şekilde hem diğer tedavi yöntemlerine destek olması hem de güvenli ve etkili bir tedavi seçeneği olması gibi avantajlarından dolayı diş hekimlerinin son zamanlarda üzerinde durduğu alternatif bir tedavi yöntemi olarak önem kazanmıştır.

Anahtar Kelimeler: botoks, botulinum toksini, onabotulinumtoksinA, klostridyum botulinum

\section{ABSTRACT}

Botulinum neurotoxin is produced by the anaerob bacterium Clostridium botulinum. The word botox take its name from the first syllable of botulinum toxin and nowadays it is used both for therapeutic and cosmetic purposes. There are 7 serotypes of botulinum toxin. The most used type is Type A. When the toxin is injected to the muscles, it effects the neurons and causes a temporary and partial paralysis ans also inhibits the abnormal contraction of the muscles. Botulinum toxin can available as different commercial names with content of firstly type $A$ and $B$ subsequently. The preparation of toxins are special for person and can not mixed with each other. Nowadays botox treatment takes a wide usage area in dentistry. Botulinum toxin begin to apply at the perioral region for therapeutic purposes in the field of dentistry for treatment of temporomandibular joint problems, bruxism, gummy smile, hypertrophic masseter, salivary glands problems. In this way botox come into prominence as an emphasized alternative treatment method among dentists with the advantages of both supporting the other treatments and becoming an efficient and safe method.

Key words: botox, botulinum toxin, onabotulinumtoxinA, clostridium botulinum

\section{GİRIŞ}

Günümüzde botoks, çizgileri ve kırışıklıkları gidermek için kullanılan kozmetik bir tedavi olarak görülmektedir. Ancak uzun zamandan beri aslında terapötik amaç için kullanılmaktadır ${ }^{1-5}$.

Servikal tonus bozuklukları, strabismus, aşırı çalışan ter bezleri durumunda, kronik kas spazmı, laringeal distoni, migren, düz kas sfinkter spazmları, miyofasiyal ağrının kontrol altına alınması gerektiğinde ve pek çok hareket bozukluklarında uygulanan etkili bir yöntemdir ${ }^{1,6-8}$. Diş hekimliğinde ise terapötik olarak botoks tedavisi uygulanmaktadır ${ }^{1-3,5,9}$.

Botulinum toksini gram pozitif anaerob bakteri olan clostridium botulinum tarafından üretilen oldukça

\footnotetext{
* T.C.Sağlık Bakanlığı Topraklık Ağız ve Diş Sağlığı Merkezi
}

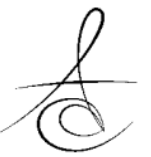


zehirli bir nörotoksindir ${ }^{1,6,8-10}$. Bilinen en zehirli biyolojik maddedir ${ }^{2,6,10}$.Çok az miktarı bile botulismus adı verilen zehirlenmeye neden olmaktadır. Botulismus; toksini vücuda salan bakteriyal sporların ince bağırsaktaki enfeksiyonuyla (enterik enfekte botulismus), yara bölgesi enfekte olduğunda veya enfekte gıdaların yenmesi sonucu toksinin gastrointestinal sistemde emilimi ile (yiyecek kaynaklı botulismus) oluşabilir ${ }^{6,10}$. Clostridium botulinum tarafından üretilen 7 tane botulinum nörotoksin serotipi vardır: $A, B, C, D, E, F, G^{1,2,10}$. Bunlardan insanlarda zehirlenmeye sebep olan tipleri $A, B$, $E$ ve nadiren $F^{\prime}$ dir. Hayvanlarda ise $C$ ve $D^{\prime} d^{2} r^{2,6,11}$.C serotipi 1 ve 2 olmak üzere 2 çeşittir $^{2,11,12}$, o yüzden bazı kaynaklarda 8 tip olarak görülmektedir ${ }^{8}$. Bu 7 tane nörotoksin immünolojik olarak farklıdır ancak yapısal olarak benzerdir ${ }^{2}$. Botulinum toksininin ticari serotipi olan A ve daha az oranda B tipi, kozmetik ve medikal amaçlı olarak kullanılmaktadır ${ }^{1,3,6,9}$.

\section{Tarihçe}

Botulinum toksininin terapötik amaçla ilk kullanımı Alman fizikçi ve şair Justinus Kerner (1786-1862) tarafından ortaya atılmıştır ${ }^{2,10}$. Bozuk sosislerden geçtiği için sosis zehiri olarak isimlendirmiştir.1870 yılında John Muller Latince kökenli olan botulismus terimini bulmuştur ${ }^{2,6,10}$. 1897 yılında Van Ermengem çiğ domuz etinin tüketilmesi ile epidemik botulismusun meydana geldiğini bulmuştur ${ }^{2,13}$. Botoksla 20.yy'da pek çok ülkede biyolojik silah geliştirilse de bununla ilgili çalışmalar durdurulmuştur ve daha sonra botoksun terapötik amaçla kullanımıyla farklı alanlara kayılmıştır².

Bu toksin 1970'lerin sonlarına doğru aşırı kas kontraksiyonu veya ağrıyı tedavi amacıyla klinik olarak kullanılmaya başlanmıştır ${ }^{8}$. 1981'de oftalmoloji uzmanı Alan Scott botulinum toksini ile strabismus tedavisi yaparak bu toksinle yapılan tedavi çalışmalarının öncüsü olmuştur ${ }^{6}$. BTX-A 1987'den bu yana da derin yüz çizgileri için kozmetik amaçlı da kullanılmaya başlamıştır ${ }^{8}$.

\section{Etki mekanizması}

Bütün serotipler benzer yapı ve moleküler ağırlığa sahiptir. Tüm tiplerde yapı disülfit bağıyla bağlı ağır ve hafif zincirlerden oluşur. Tüm serotipler aynı mekanizma ile etki etmektedir ancak farklı zehirleme etkileri vardır. En etkili olan ve en çok kullanılan ise Tip A (BTX-A)'dır 2,6,8,13,14.

Aktivitesi fazla olan kaslara botulinum toksini verildiğinde kasta paraliz meydana gelmekte ve kas aktivitesi azalmaktadır. Bu azalma verilen doza göre farklılık göstermektedir ${ }^{2,3,15}$.
Botulinum toksini, tüm parasempatik ve kolinerjik sinir uçlarındaki iletimi sağlayan asetilkolinin salınımını inhibe ederek etkisini gösterir ${ }^{1,3,6,8,10,13}$. Öncelikle toksin ağır zinciri vasıtasıyla presinaptik reseptörlere bağlanmakta ve sinirin içine girmektedir. Hafif zincir molekülü ile vezikül duvarına geçiş yaparak endopeptidaz etki ile (proteaz enzimi sayesinde) snare proteini olan SNAP 25'i (25-kd synaptosomal bağlantılı protein) parçalamaktadır. (Snare proteinleri, maya ve memeli hücrelerinde bulunan geniş bir protein ailesidir. Esas rolleri vezikül birleşimine aracilık etmektir. Bu proteinler botulismus ve tetanozdan sorumlu bakteriyel nörotoksinlerin hedefidir ${ }^{16,17}$.) Bu şekilde nörotransmiterin salındığı membrana bağlanan asetilkolinin depolandığı keseciklerden asetilkolin salınımını önlemektedir. (Resim 1)

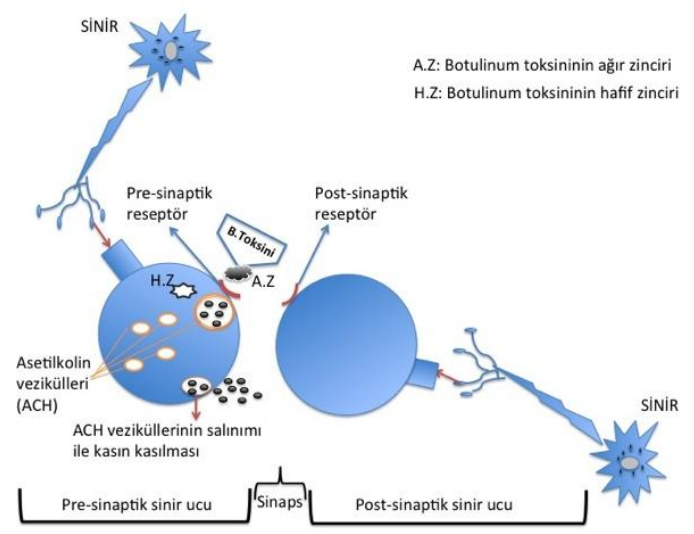

Resim 1. Parasempatik veya kolinerjik sinir uçlarının șematik gösterimi. Presinaptik sinir ucuna ağır zincir vasıtasıyla bağlanan botulinum toksini sinir içine girerek hafif zincir molekülü ile membrana girmekte ve asetilkolin salınımını inhibe etmektedir.

Botoks (BTX) kasta kısmi kimyasal bozulma meydana getirerek kas aktivitesinde azalma veya paraliz meydana getirmektedir. Etki süresi 3-6 ay arasında değişmektedir ${ }^{1-3,6,8-10,13}$.

Botulinumun in vitro uygulamalarında glutamat, CGRP (calcitonin gene related peptide), $\mathrm{P}$ maddesini ve vazopresini etkilediği görülmüştür. Ancak aynı prosedürün terminal duysal sinir uçlarındaki etkisi bilinmemektedir.

Toksinin alımından sonra inkübasyon süresi 18-36 saat olarak belirtilse de ${ }^{2,10}$, klinik etki ortalama olarak 3-7 günde meydana gelir. Takiben 1-2 haftada en yüksek seviyeye ulaşır. Eşik seviyesi tam sinir iyileşmesine kadar (3-6 ay) düz bir seyir gösterir ${ }^{2,12}$.

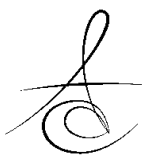




\section{Toksisite}

Botulinum toksini 3 anahtar protein içeren yüksek moleküler ağırlıklı protein kompleksidir. Bu proteinler; 150 kDA (kilodalton; ağırlık birimi) toksin, toksik olmayan hemaglutenin proteini ve toksik olmayan non hemaglutenin proteinidir. kDa toksininin hafif ve ağır zincirleri vardır ve her iki zincir de nörotoksisite için gereklidir. Tip A toksinine maruz kalan bir insan popülasyonunun (yaklaşık $70 \mathrm{~kg}$ ağırlıklarında olan) \%50 ‘si için öldürücü doz intravenöz olarak 0.09$0.15 \mu \mathrm{g}$, inhalasyonla 0.7-0.9 $\mu \mathrm{g}$, oral olarak $70 \mu \mathrm{g}$ 'dır. Yapılan çalışmalarda kasa uygulanacak botoks enjeksiyonu yaklaşık 2500-3000 U'dir ${ }^{2,4,11,12 . ~(70 ~ k g . l ı k ~}$ yetişkin bir insanda $35-40 \mathrm{U} / \mathrm{kg}$ )

1 enzim birimi $=(U)=1 \mu \mathrm{mol} \min ^{-1}$ (Enzim miktarları, diğer kimyasal bileşikler gibi, molar birim ile ifade edilebilir veya aktivite cinsinden enzim birimi ile ölçülebilir. $)^{18}$

\section{Hazırlanışı ve İcerikleri}

Botolinum toksini farklı çeşitlerde preparatlara sahiptir $^{2,4}$. BTX'un ticari isimleri ve menşei ülkeler şöyledir $2,3,9,13$ :

- Botox (BTX-A, Allergan, Irvine, ABD)

- Dysport (BTX-A, Ipsen Ltd., Maiden-head, İngiltere)

- Xeomin (BTX-A, NT-201;Merz Pharmaceuticals, $\mathrm{GmBH}$, Almanya)

- Prosigne (BTX-A, Lanzhou Biological Products Institute, Çin)

- Myobloc (BTX-B, Solstice Neurosciences, Inc., San San Francisco, ABD)

- Wako (BTX-B, Wako Chemicals, Richmond, VA, $\mathrm{ABD})^{4}$

- Neurobloc (BTX-B, Eisai Ltd., Hatfield, İngiltere)

Botulinum toksininin preparatları piyasada farklı bir isimle de bilinmektedir. Botox onabotulinum tok$\sin A(O N A)$, Dysport abobotulinum toksinA (ABO), Xeomin incobotulinum toksinA ve Myobloc ise rimabotulinum toksinB olarak da adlandırılmaktadır. Ancak bu isimler henüz tescillenmiş değildir ${ }^{19,20}$.

BTX'un tedavi dozu kullanılan toksinin markasına göre değişir. Herhangi bir toksin çeşidi için verilen doz sadece belirli preparat için geçerlidir ve aynı toksininin serotipi olmadığı sürece diğer ürünün dozlarına ilave veya aktarma olamaz. Toksinin dozu çok iyi ayarlanmalıdır çünkü farklı preparatlar vücudun farklı kısımlarında değişen etkilere sahiptir².

\section{BTX-A}

Botox:Botoks(Allergen, Irvine, Calif) C.botulinumun fermentasyonundan izole edilen saflaştırılmış BTX-A'dır. Esas ismi Oculinum olan BTX-A insanlarda ilk olarak 1968'de strabismus tedavisinde kullanılmıştır. Bu salin solüsyonu ile dilüe edilmiş vakumla kurutulmuş bir tozdur. Allergan firması 1991'de saflaştırılmış btx-a'yı alarak Botox ticari ismiyle piyasaya sürmüştür ${ }^{2}$. Her bir flakon Botox 5 ng (nanogram) (100 U) havada kurutulmuş toksin içerir. Bunun 1 ünitesi 18-20 gr. dişi farelerin periton içine yapılan enjeksiyonunda $\% 50$ 'sini öldürücü etkiye sahip ortalama dozdur. Ayrıca flakonlarda $500 \mu \mathrm{g}$ albümin ve $900 \mu \mathrm{g}$ steril vakumla kurutulmuş sodyum klorit (koruyucu madde içermeyen) vardır ${ }^{1,2,13,21}$.

Dysport ise $12.5 \mathrm{ng}(500 \mathrm{U})$ havada kurutulmuş toksin, $125 \mu \mathrm{g}$ albümin ve $2.5 \mathrm{mg}$ laktoz içerir. Dysport farklı bir tip A bakteri cinsinden geldiği için Botox ile dozları aynı değildir ${ }^{2}$. Ayrıca $1 U$ Botox, $1 U$ Dysport'a göre 3 kat daha toksiktir ${ }^{22}$.

Xeomin dondurularak kurutulmuş saflaştırılmış ve yardımcı kompleks proteinler (hemaglutinin ve nonhemaglutinin) içermeyen btx-a'dır ${ }^{2,23,24}$. Diğer btx-a ürünlerinden daha az immünojeniktir ${ }^{2}$. Ayrıca diğer btx formları dolapta saklanabilirken oda ISIsında saklanabilen tek formdur ${ }^{25}$.

Prosigne ise piyasada henüz yeni bir üründür ve Botox'la bazı terapotik kullanımlarda benzer özelliklere sahiptir ancak klinik çalışmalara intiyaç vardır ${ }^{26}$.

Purtox da saflaştırılmış btx-a'dır ve bazı terapötik kullanımlardaki etkinliği klinik olarak araştırılmaktadır ${ }^{2}$.

Myobloc, kozmetik kullanımdan çok hareket bozukluklarının tedavisinde etkindir. 2001'de, FDA tarafından sadece servikal distoni ve hemifasiyal spazmların tedavisinde kullanım için onaylanmıştır ${ }^{2}$. Göz kapağı düşüklüğü olan vakalarda, bazı kırışıklıklar için ve kozmetik nöroblokaj için btx-a ürünlerine direnci olan hastalarda alternatif olarak kullanılabilir ${ }^{2,25}$.

Myobloc flakonlarında dozlar sulandırılmış olarak $25 \mathrm{ng}(2500 \mathrm{U}) / 0.5 \mathrm{cc}, 50 \mathrm{ng}(5000 \mathrm{U}) / 1.0 \mathrm{cc}, 100$ ng $(10.000 \mathrm{U}) / 2.0 \mathrm{cc}$ olacak şekilde $\% 0.05$ albüminle birlikte bulunur. $1 \mathrm{U}$ Botox yaklaşık olarak 50-100 U Myobloc miktarına denk gelmektedir ${ }^{2}$.

Btx-a kristalize bir formdadır ve normal salinle sulandırılabilir. Btx-b ise asidik bir solüsyondadır ve ağrılı enjeksiyonlara neden olabilir ${ }^{25}$. 


\section{Saklama Kossulları}

Botulinum toksinleri $2-8^{\circ} \mathrm{C}^{\prime}$ deki dolapta 2 yıl saklanabilir. Sulandırımış formu ise $4^{\circ} \mathrm{C}^{\prime}$ de 6 hafta klinik etkinliğini koruyabilir ${ }^{13,19,27}$. Flakonlar üretici firmanın önerileri doğrultusunda saklanmalı ve doğrudan gün ışı̆ğna veya toksindeki proteini denatüre edecek ısıya maruz bırakılmamalıdır. Güneğ ışı̆ına doğrudan maruz kalan toksin 1-3 saat içinde, $80^{\circ} \mathrm{C}^{\prime}$ deki ısıda $30 \mathrm{dk}$.da, $100^{\circ} \mathrm{C}^{\prime} \mathrm{de}$ ise $10 \mathrm{dk}$.da inaktive olmaktadır. Botulinum toksinleri kolaylıkla denatüre olabilen toksinlerdir. Ayrıca toksinin konsantrasyonu, ortamın pH'sına bağı olarak ISI arttıkça çok daha kısa sürede bozulabilmektedir. C.botulinum sporları ise daha dayanıklı olup $120^{\circ} \mathrm{C}^{\prime}$ de $15 \mathrm{dk}$.dan uzun sürede bozulmaktadır. ${ }^{12,27}$.

Diș hekimliğindeki endikasyonları $1,3,7$

1. Temporomandibular eklem rahatsız||kları ${ }^{2}$

2. Bruksizm

3. Görünür dişeti (Gummy smile) ${ }^{1,3,7}$

4. Masseter hipertrofisi ${ }^{2}$

5. Mandibular spazm

6. Oromandibular distoni ${ }^{2}$

7. Sialore ${ }^{2}$

8. Trigeminal nevralji ${ }^{1,2,7}$

9. Dental implant ve hareketli protezler(çiğneme kaslarının hiperfonksiyonu durumunda)

10. Ortodontik tedavinin geri döndügüu durumlar

11. Maksillofasiyal cerrahi

1- Temporomandibular Eklem Rahatsızlıklar1 ${ }^{1-3,28}$

TME bozuklukları çiğneme kaslarının disfonksiyonu gibi eklem patolojisini de içerir. Eklem bozukluklarında birincil etken miyojeniktir (kassal) ve kas kasılması şeklinde olur. İkincil etyolojik faktörler olarak bruksizm, dış stres kaynakları, ağız çene kaslarında (oromandibular) distoni ve psikomotor davranışları içerebilir.

Eklem rahatsızlıkları aşıı çiğneme kuvvetinden kaynaklanabilir. Bu durumda ağı içi apareyler, oklüzal uyumlamalar, restorasyonlar ve/veya cerrahi ile tedavi sağlanabilir. Bu teknikler invaziv, geri dönüşümsüz ve pahalıdır.

Şu anda kullanılan estetik ve konservatif uygulamalar parafonksiyonel kuvvetlere direnebilecek şekilde değildir. O yüzden bu tedavi seçeneklerinin pek çoğu tüm hastalar için ideal değildir. Botulinum toksini A ile sağlanacak kas relaksaksiyonu (gevşemesi) alternatif bir tedavi yöntemidir. Kaslarda bir ya da daha fazla trigger noktası mevcuttur. Bu noktaların palpasyonu ağrının kas boyunca nöronal yolla yayılmasına neden olur. Steril salin ve lokal anestezik ajanlar doğrudan trigger noktalara enjekte edilerek kullanılmaktadır. Ayrıca enjeksiyonlar genellikle yüzün tek tarafı etkilense bile kasa çift tarafı olarak yapılmalıdır. Trigger noktalarının engellenmesi kısa ya da uzun vadede rahatlama sağlamaktadır. Ancak bunların etkisi birkaç gün sürmektedir. Botoksta ise bu etki daha uzun ve etkilidir ${ }^{3}$.

\section{2- Bruksizm ${ }^{1-3,29}$}

Botulinum nörotoksini bruksizm semptomlarını hafifletici etkiye sahiptir. Tip A botulinum toksininin kullanımı ile ilgili ilk rapor Van Zandijcke ve Marchau tarafından bildirilmiştir. Beyin hasarı olan ve şiddetli bruksizm olan hastada $100 \mathrm{U}$ botulinum toksini temporal ve masseter kaslarına enjekte edilerek tedavi sağlanmıştır. Toksin bilateral olarak masseter ve temporal kasa enjekte edilir. Doğru doz çiğneme ve konuşma etkinliği açısından önemlidir.

\section{3-Görünür Dișeti (Gummy Smile) ${ }^{1,3,8}$}

Gülüș sırasında fazla gingival dokunun görünmesi 'görünür dişeti' (gummy smile) olarak adlandırılmaktadır. Etiyolojik nedenleri; iskeletsel (maksillanın vertikal gelişiminin fazla olması), gingival (gecikmiş pasif erüpsiyon, dişetinin insizale uzayarak dişi kapatması), kassal (hiperfonksiyonel kastan dolayı üst dudağın yukarı kalkması), iatrojenik veya bunların kombinasyonu olabilir. Üst dudak elevator kaslarının (özellikle levator superioris alaque nasi) hiperfonksiyonuna bağlı olarak meydana gelen dişeti görünürlüğü durumlarında cerrahi olmayan bir yöntem olarak botoks avantajlı olmaktadır ${ }^{3,8}$.

Botulinum toksini küçük miktarlarda dikkatli bir şekilde titre edilmiş dozlarda üst dudak kasına enjekte edilerek diş etlerinin görünürlüğünün azalması sağlanmaktadır. Yonsei noktası adı verilen bir noktaya enjeksiyon yapılması önerilmiştir. Bu nokta levator labii superioris, levator labii superioris alaque nasi ve zygomaticus minor kasları tarafından oluşturulan üçgenin merkezine yapılmalıdır. Önerilen doz ise her bir enjeksiyon bölgesine $3 U$ 'dir. Enjeksiyonun etki süresi 3 ila 6 ay arasında değişmektedir. Etkileri geçici olup 6ay ile 1 yıl arasında tekrarlanmalıdır ${ }^{1}$.

\section{4- Masseter Hipertrofisi ${ }^{1,29}$}

Kronik olarak diş gıcırdatan hastalarda hipertrofi sıklıkla görülmektedir. Masseter kasının kütlesindeki artış yüzde estetik bozulmalara yol açmaktadır. Kastaki hiperaktiviteyi azaltmak için $30 \mathrm{U}$ doz ile 
botulinum toksininin verilmesi kas kütlesinde azalma sağlamaktadır (maksimum azalma \%35.4).

\section{5- Mandibular Spazm ${ }^{1,13,30}$}

Mandibulayı kapatan kaslar spasm şeklinde kalmışsa ağız açıklığı kısıtlanır. Bu tip bir kas spasmı oral hijyenin sağlanması için gerekli ağız bakımını ve yemeyi kısıtlar. Botulinum toksini ile kas sisteminin hipertrofisi veya spastik kasların tedavisi sağlanabilmektedir. Spasm için uygulanacak etkili doz hipertrofik kas tedavisi ile aynı olup massetere $30 \mathrm{U}$ botulinum toksinin enjeksiyonu şeklindedir. Amaç sorun olan kasa enjeksiyon yapılarak spazmın çözülmesidir.

\section{6- Oromandibular Distoni ${ }^{1,2,3}$}

Oromandibular distoni çiğneme ve alt yüz kaslarının disfonksiyonu ve istemsiz kasılmalarla seyreden bir hareket bozukluğudur. Konuşma, yutkunma ve yemede zorlukla kendini gösterir. Nörolojik bir rahatsızlık olmasına rağmen masseter bölgesini ilgilendirdiğinden temporomandibular rahatsızlıklar altında incelenir. Botulinum toksini tip A massetere ve/veya submentale yapılmaktadır. Aynı zamanda temporal ve lateral pterygoid kaslar da etkilenebilmektedir ${ }^{6}$. Bunlara yapılacak botulinum toksininin başlangıç dozu masseter için tek tarafa $20 \mathrm{U}$, temporal kasa $25 \mathrm{U}$ ve pterygoid kasa ise $10 \mathrm{U}$ 'dir. Bu dozlar klinik vakanın ağırlığına göre artabilirr ${ }^{13}$. Çiğneme ve konuşma fonksiyonundaki gelişmelerin \%67.9 oranında olduğu bildirilmiştir.

\section{7- Sialore ${ }^{1-3,9}$}

Tükürük akışının fazlalığı olarak bilinen sialorenin tedavisi davranışsal terapi ve scopolamin gibi ilaçlarla olmaktadır. Günümüzde botoks enjeksiyonunun parotis veya maksiller tükürük bezine yapılmasıyla kolinerjik reseptörlerin stimülasyonu engellenerek sialore tedavi edilmektedir. Kolinerjik parasempatik salgı uyarıcı lifleri bloke edildiği için botulinum toksini, yemek borusunun rahatsızlıkları, serebral palsi, aşırı terleme ve dilden terleme (parotis bezinin çalışmamasına bağlı tükürük eksikliği= Frey sendromu) gibi bazı otonomik rahatızlıklar için de denenmektedir.

\section{8- Trigeminal Nevralji ${ }^{1-3,7}$}

Trigeminal nevralji, trigeminal sinirin bir veya daha fazla dalına yayılmasıyla sınırı olan keskin tek taraflı yüz ağrısı durumudur. 25-75 U botoks perikraniyal kaslara enjekte edilmekte ve trigger noktasındaki sinir iletimini bloke ederek aktif kasların rahatlamasını sağlamaktadır.

9- Dental implant ve hareketli protezler ${ }^{1-3}$
Çiğneme kaslarının aşırı yüklemesi implant osseointegrasyonunu engelleyebilmektedir. Kaslara botulinum toksini verilerek terapötik olarak implantın aşırı yüklenmesi ile oluşabilecek osseointegrasyon kaybı ve kırık oluşumu önlenebilir. İmplant tedavisini karşlayamayan veya kontrendikasyonu olan hastalarda hiperaktif kas fonksiyonu nedeniyle stabilitesini kaybeden protezleri ağızda tutabilmek için de botoks yapılmaktadır.

\section{0- Ortodontik tedavi ${ }^{1,3}$}

Mental kas gibi güçlü kas aktivitesine sahip hastalarda ortodontik tedavi sonrasında relapsı önlemek için kullanılabilir Botoks tedavisi ile kas kontraksiyonu azalmakta ve kaslar işlevini normal bir şekilde yerine getirmektedir.

\section{1- Maksillofasiyal cerrahi ${ }^{1,2}$}

Yüksek dozda botulinum toksini tip A tedavi edici splint olarak kullanılabilir. Fasiyal kemik veya mandibular kondil kırığı durumunda, kırık uçlarında rijit bir internal fiksasyon sağlanması mümkün değilse hareketin azalması ve kırık parçalara bağlı kasların kontraksiyonunun azalması için botoks uygulanabilir. Fasiyal kemik veya mandibular kondil kırığının tedavisinde kas kontraksiyonunu sınırlayarak işlev görür.

\section{Kontrendikasyonları ${ }^{1,2,31}$}

- Yüksek beklentiye sahip kişiler

- Mimiklerin önemli olduğu kamera önünde çalışan insanlar

- Nöromusküler rahatsızlıkları olanlar (ör; myastenia gravis, Eaton-Lambert sendromu)

- BTX-A veya BTX-B bileşenlerinden birine (ör;albümin, laktoz, maden tuzu, sodyum süksinat) allerjisi olanlar

- Nöromusküler uyarı iletimi ile ters etki oluşturabilecek ve botoksun etkisini artıracak (ör; aminoglikozit, penisilamin, kinin ve kalsiyum blokerleri) belirli ilaçlar alınıyorsa

- Hamile ve emziren hastalarda (botoks hamilelik kategorisinde $\mathrm{C}$ grubudur.)

- 12 yaş altı hastalar

\section{Botoksun kozmetik kullanımı}

Yüzdeki kırışıklıkları azaltmak amacıyla botoksun intramuskuler uygulaması en yaygın kozmetik uygulamalardan biridir. Botoks yüz kaslarının hareketinden kaynaklanan değişikliklerin yeniden şekillendirilmesine olanak verir. Botoks A'nın kozmetik potansiyeli ilk olarak 1980 'lerin ortasında keşfedilmiştir. Botulinum 
toksininin estetik durumlar için tanımlanan ilk kullanımı 1989'da bir ritidektomi (yüz germe) ameliyatı sonrası oluşan fasiyal paralizinin sebep olduğu fasiyal asimetriyi düzeltmek içindir ${ }^{32}$. 1992'de Carruthers and Carruthers ${ }^{33}$ toksinin kullanımı ile derin glabellar kırışıklıkların görünümünde olumlu etki rapor etmişlerdir. Bundan sonra toksinin yüz gençleştirmede kullanımı yaygınlaşmıştır fakat bu uygulamalar resmi olarak onaylı değildir. A.B.D. Gıda ve İlaç Dairesi 2002'de botulinum toksin tip A'nın sadece orta ve şiddetli glabellar kırışıklıklar için kullanımını onaylamıştır ${ }^{34}$. Fakat frontalis ve lateral kantal bölgeler için kullanımı da aynı derecede iyileşme göstermiştir. Bundan sonra glabellar çizgilerin ve horizontal alın çizgileri, lateral kantal çizgiler -kaz ayakları-, platisma bantları ve ağız çevresi çizgileri gibi diğer hiperfonksiyonel yüz çizgilerinin geçici olarak tedavisinde kullanılmıştır ${ }^{35,36,37}$. Botoksun yüz kırıșıkıklarında kullanılması randomize kontrollü çalışmalardan elde edilen 2. seviye kanıta dayanır. Mentalis kırışıklığı ve alt gözkapağı orbicularis hipertrofisi olan birkaç hasta da botoks enjeksiyonu ile başarılı bir şekilde tedavi edilmiştir ${ }^{38,39}$.

Botulinum toksinin kimyasal denerve edici etkisi başarılı bir şekilde ortaya konmuştur. Tedavi güvenli, etkili, minimal invaziv ve tekrarlanabilirdir. Yöntem nitelikli kişiler tarafından, dikkatli seçilmiş hastalar üzerinde uygulandığında gençleştirme için cerrahi olmayan etkili bir seçenek sunmaktadır.

Botoks uygulaması sonrası görülebilecek yan etkiler ve komplikasyonlar ${ }^{1,2,31,40}$

Botulinum toksinin lokal etkileri genellikle geçicidir. En çok görülen yan etki alerjidir. Ağrı, ödem, eritem, ekimoz, enfeksiyon, ağız kuruluğu, fasiyal sinir felci ve kısa dönem sinir duyarsızlığı diğer yan etkilerdir. Dozdan bağımsız olarak yorgunluk, bulantı, kaşıntı gibi geçici sistemik yan etkiler nadiren görülür. Ayrıca kaslardaki zayıflığa bağlı olarak yutma zorluğu da görülebilmektedir. Btx-B ile çalışmalar sürmektedir ancak ağız kuruluğu ve yutma zorluğu (disfaji) btx-A'ya göre daha fazla görülmektedir.

\section{Dis Hekimlerinin botoksu uygulama}

\section{yetkinliği}

Son zamanlara oral ve perioral bölgelere botoks uygulaması oldukça artmıştır ${ }^{3}$.

Diş hekimliğinde botoks uygulamasına yönelik kursların yoğunlaşması ile bu kurslardan alınan sertifikalar doğrultusunda diş hekimleri perioral bölgede botoks uygulaması yapabilmektedir. Aynı zamanda diş hekimlerinin baş, boyun anatomisine hakim olmaları, el becerilerinin gelişmiş olması botoksun uygulanabilirliğini artırmıştır. Ancak Sağlık Bakanlığı Sağlık Hizmetleri Genel Müdürlüğü'nün konuya ilişkin 15.08 . 2015 tarihinde yayınladığı yazıda "botoks (botulinum toksin) işlemi, botulinum toksin adı verilen bakteriden elde edilen tıbbi bir ilacın uygulandığı yerlerle bağlantılı olarak olası komplikasyonları nedeniyle de uygulandığı alanla ilgili eğitimi gerektiren tıbbi bir girişimdir. Ülkemizde bu işlemin yüz bölgesinde uygulanmasına ilişkin eğitim, Plastik, Rekonstrüktif ve Estetik Cerrahi ve Dermotoloji yeni adıyla Deri ve Zührevi Hastalıklar Uzmanlık eğitimi içinde verilecektir. Yani botoks işlemini yüz estetiği alanında uygulayabilmek için, hekimlik sıfatına sahip olmanın yanı sıra, bu uzmanlık dallarında eğitim görmüş olmak da bir zorunluluktur. Bu şartları taşımaksızın, hekim dışı kişilerin çeşitli kurslardan edindikleri bilgiye veya belgeye dayanarak hekimlik alanında mesleki faaliyette bulunması mümkün değildir" demektedir ${ }^{41}$.

Dolayısıyla bu yazı doğrultusunda diş hekimlerine botoks uygulaması ile ilgili kısıtlama getirilmiştir. Dünyada botoksun diş hekimleri tarafından sınırlı alanlarda uygulandığı bilinmektedir ${ }^{30}$. İngiltere'de genel diş hekimliği konseyinin aldığı kararda ise diş hekimlerinin perioral bölgede botoks işlemini yapabileceği ancak bu alan dışında çalışamayacağı belirtilmiştir ${ }^{42}$.

ADA'nın 2013'te verdiği kararla Amerika'da 20'den fazla eyalette diş hekimleri belirli kursları gördükten sonra botoks uygulayabilmektedir. Eyaletlere göre endikasyonlar kozmetik ve dental uygulama şeklinde farklılıklar gösterebilmektedir. Ancak özellikle eklem problemlerini çözmek amacıyla eklem bölgesine, oral bölgeye rahatlıkla uygulanabileceği kararı alınmıştır. Bazı eyaletlerde ise sadece oral ve maksillofasiyal cerrahlar için uygulama yapılması şartı bulunmaktadır $^{43,44}$.

\section{SONUÇ}

Günümüzde estetik diş hekimliği alanında artık botoks da uygulanmaktadır. Estetik beklentilerin yanısıra tedavi amaçlı olarak da yapılan botoks ile temporomandibular bölgedeki problemler, bruksizm veya görünür dişeti tedavisi de uygulanmaktadır. Diş hekimlerinin perioral bölgede botoksu tedavi amaçlı olarak uygulaması ile ilgili yasal izinler ülkelere gore değişmektedir. Uygulama sırasında önemli olan uygun 
dozda ve gerekli olan kasa enjeksiyon yapılarak tedavinin sağlanmasıdır.

\section{KAYNAKLAR}

1- Nayyar P, Kumar P, Nayyar PV, Singh A. BOTOX: Broadening the Horizon of Dentistry. J Clin Diagn Res. 2014;8:25-29.

2- Majid OW. Clinical use of botulinum toxins in oral and maxillofacial surgery. Int J Oral Maxillofac Surg. 2010;39:197-207.

3- Sinha A, HurakadliM, Yadav P. Botox and derma fillers: The twin face of cosmetic dentistry. Int J Contemp Dent Med Rev. 2015; doi:10. 15713/ ins.ijcdrm. 27.

4- Scott AB, Suzuki D. Systemic toxicity of botulinum toxin by intramuscular injection in the monkey. Mov Disord. 1988;3:333-335.

5- Binder WJ, Blitzer A, Brin MF. Treatment of hyperfunctional lines of the face with botulinum toxin A. Dermatol Surg. 1998;24:1198-1205.

6- Münchau $A$, Bhatia KP. Uses of botulinum toxin injection in medicine today. BMJ. 2000;15:161-5.

7- Ngeow WC, Nair R. Injection of botulinum toxin type A (BOTOX) into trigger zone of trigeminal neuralgia as a means to control pain. Oral Surg Oral Med Oral Pathol Oral Radiol Endod. 2010;109:47-50.

8- Polo M. Botulinum toxin type $A$ in the treatment of excessive gingival display. Am J Orthod Dentofacial Orthop. 2005;127:214-218.

9- Fuster Torres MA, Berini Aytés L, Gay Escoda C. Salivary gland application of botulinum toxin for the treatment of sialorrhea. Med Oral Patol Oral Cir Bucal 2007;12:511-7.

10-Dastoor SF, Misch CE, Wang HL. Botulinum toxin (Botox) to enhance facial macroesthetics: a literature review. J Oral Implantol 2007;33:164-71.

11-CIDRAP - Center for Infectious Disease Research and Policy. Botulism. [internette].2012. [01/11/ 2015 okundu] elektronik adresi: http://www.c idrap.umn.edu/infectious-disease-topics/botulism

12-CFSPH: The Center for Food Security and Public Health (CFSPH). Botulism [internette]. 2010. [ 07/ 11/2015 okundu] elektronik adresi: http://www. cfsph.iastate.edu/Factsheets/pdfs/botulism.pdf. okundu.
13-Alshadwi A, Nadershah M, Osborn T. Therapeutic applications of botulinum neurotoxins in head and neck disorders. Saudi Dent J. 2015;27:3-11.

14-Wang L, Sun Y, Yang W, Lindo P, Singh BR. Type $A$ botulinum neurotoxin complex proteins differentially modulate host response of neuronal cells. Toxicon. 2014;82:52-60.

15-Üner DD, İzol BS, İpek F, ElbirM, Tosun B. Dudağın yeniden konumlandırılması ve gingivektomi yapılarak gummy smile tedavisi bir olgu sunumu (Gummy Smile). Atatürk Üniv Diş Hek Fak Derg 2015;10:25-9.

16-Wikipedia, the free encyclopedia, Snare. [internette]. 2015. [01/11/2015 okundu]. elektronik adresi: http://en.wikipedia.org/ wiki/ SNARE (protein)

17-Davletov B, Bajohrs M, Binz T. Beyond BOTOX: advantages and limitations of individual botulinum neurotoxins. Trends Neurosci. 2005;28:446-452.

18-Vikipedi, özgür ansiklopedi, Enzim ölçümü. [internette]. 2013. [10/11/2015 okundu]. elektronik adresi: https://tr.wikipedia.org/ wiki /Enzim_ölçümü

19-Chen JJ, Dashtipour K. Abo-, inco-, ona-, and rimabotulinum toxins in clinical therapy: a primer. Pharmacotherapy. 2013;33:304-18.

20-Dressler D, Mander G, Fink K. Measuring the potency labelling of onabotulinumtoxinA (Botox) and incobotulinumtoxinA (Xeomin) in an LD50 assay. J Neural Transm. 2012;119:13-5.

21-Vartanian, A.J., Dayan, S.H. Complications of botulinum toxin $A$ use in facial rejuvenation. Facial Plast Surg Clin North Am. 2003;11:483-92.

22-Odergren $T$, Hjaltason $H$, Kaakkola S, Solders $G$, Hanko J, Fehling $C$, et al. A double blind, randomised, parallel group study to investigate the

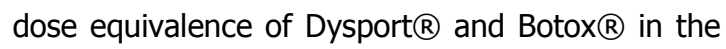
treatment of cervical dystonia. J Neurol Neurosurg Psychiatry 1998;64:6-12.

23-Wohlfarth K, Müller C, Sassin I, Comes G, Grafe S. Neurophysiological double-blind trial of a botulinum neurotoxin type a free of complexing proteins. Clin Neuropharmacol. 2007;30:86-94.

24-Roggenkämper P1, Jost WH, Bihari K, Comes G, Grafe S; NT 201 Blepharospasm Study Team. Efficacy and safety of a new Botulinum Toxin Type A free of complexing proteins in the treatment of

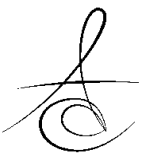


blepharospasm. J Neural Transm (Vienna). 2006;113:303-12.

25-Hellman A, Torres-Russotto D. Botulinum toxin in the management of blepharospasm: current evidence and recent developments. Ther Adv Neurol Disord. 2015;8:82-91.

26-Rieder CR, Schestatsky P, Socal MP, Monte TL, Fricke D, Costa J, Picon PD. A double-blind, randomized, crossover study of prosigne versus botox in patients with blepharospasm and hemifacial spasm. Clin Neuropharmacol 2007; 30:39-42.

27-Lam, S.M. The basic science of botulinum toxin. Facial Plast. Surg. Clin. North Am 2003;11:431-8.

28-Kurtoglu C, Gur OH, Kurkcu M, Sertdemir Y, GulerUysal $F$, Uysal $H$. Effect of botulinum toxin-A in myofascial pain patients with or without functional disc displacement. J Oral Maxillofac Surg 2008;66:1644-51.

29-Kim HJ, Yum KW, Lee SS, Heo MS, Seo K. Effects of botulinum toxin type $A$ on bilateral masseteric hypertrophy evaluated with computed tomographic measurement. Dermatol Surg. 2003;29:484-490.

30-Cersosimo MG, Bertoti A, Roca CU, Micheli F. Botulinum toxin in a case of hemimasticatory spasm with severe worsening during pregnancy. Clin Neuropharmacol. 2004;27:6-8.

31-Orbak R, Öztürk M. İntraoral tedavileri tamamlayıcı perioral bölgedeki estetik çalışmalar. Atatürk Üniv. Diş Hek. Fak. Derg. 2014;24: 427-433.

32-Clark, R. P., and Berris, C. E. Botulinum toxin: A treatment for facial asymmetry caused by facial nerve paralysis. Plast. Reconstr. Surg. 1989;84:353-5.

33-Carruthers, JD, and Carruthers, JA. Treatment of glabellar frown lines with $C$. botulinum-A exotoxin. J. Dermatol. Surg. Oncol. 1992;18:17-21.

34-U.S. Food and Drug Administration. Botox medication guide. FDA approves Botox to treat frown lines. [internette]. 2002. [12/11/2015 okundu]. elektronik adresi: http://www.f da.gov/ bbs/ topics/AN- SWERS/2002/ ANS01147.html.

35-Fagien S, Brandt FS. Primary and adjunctive use of botulinum toxin type $A$ (Botox) in facial aesthetic surgery: beyond the glabella. Clin Plast Surg 2001;28:127-48.

36-Frampton JE, Easthope SE. Botulinum toxin A (Botox cosmetic): a review of its use in the treatment of glabellar frown lines. Am J Clin Dermatol 2003;4:709-25.

37-Niamtu J. Aesthetic uses of botulinum toxin A. J Oral Maxillofac Surg 1999;57: 1228-33.

38-Flynn TC, Carruthers J, Carruthers A. Botulinum-A toxin treat- ment of the lower eyelid improves infraorbital rhytides and widens the eye. Dermatol Surg 2001;27: 703-708.

39-Niamtu J. Botulinum Toxin A: A Review of 1,085 Oral and Maxillofacial Patient Treatments. J Oral Maxillofac Surg 2003;61:317-324.

40-Schantz EJ and Johnson EA. Properties and Use of Botulinum Toxin and Other Microbial Neurotoxins in Medicine. Microbiol.Rev. 1992;56:80-99.

41-İstanbul diş hekimleri odası, Diş hekimliğinde botoks uygulaması hakkında duyuru. [internette].2015. [ 04/12/2015 okundu] elektronik adresi:https://www.ido.org.tr/lib_upload/files/Ek\% 202.PDF

42-Lyall J. Dental Protection raises concerns about botox (News). Br Dent J. 2008;205:115.

43-Sarrett D. A Discussion about Dermal fillers, Botox and Dentistry. ADA Professional Product Review (A Publication of the Council on Scientific Affairs). 2015; 10:4-9.

44-Kelly Soderlund, ADA News staff. Massachusetts approves Botox policy for dentists [internette]. 2013. [ 02/11/2015 okundu] elektronik adresi: http://www.ada.org/en/publications/ada-news/ 2013-archive/april/massachusetts-approves-botoxpolicy-for-dentists.

\author{
Yazışma Adresi \\ Dr. Dt. Gökçe SOĞANCI \\ Protetik Diş Tedavisi Uzmanı \\ T.C.Sağlık Bakanlığı \\ Topraklık Ağız ve Diş Sağlığı Merkezi \\ Kurtuluş-Ankara \\ 05326420486 \\ dt.gokce@hotmail.com
}

